\title{
Evaluation of Watermelon and Related Species for Resistance to Race 1W Powdery Mildew
}

\author{
Angela R. Davis ${ }^{1}$ \\ United States Department of Agriculture, Agricultural Research Service, South Central Agriculture \\ Research Laboratory, P.O. Box 159, Lane, OK 74555

\begin{abstract}
Amnon Levi
United States Department of Agriculture, Agriculture Research Service, U.S. Vegetable Laboratory, Charleston, SC 29414
\end{abstract}

Antonia Tetteh and Todd Wehner
North Carolina State University, Raleigh, NC 27695-7609

Vincent Russo

United States Department of Agriculture, Agricultural Research Service, South Central Agriculture Research Laboratory, P.O. Box 159, Lane, OK 74555

Michel Pitrat

INRA, UR1052, Génétique et Amélioration des Fruits et Légumes, BP 94, F-84140 Montfavet, France

Additional Index words. Citrullus lanatus, Podosphaera xanthii, Sphaerotheca fuliginea, Cucumis melo, pathotype

\begin{abstract}
Powdery mildew [Podosphaera xanthii (Castagne) Braun \& Shishkoff (syn. Sphaerotheca fuliginea auct. p.p.)] is now a common disease on watermelon [Citrullus lanatus (Thunb.) Matsum. \& Nakai] in the United States. In this study, the entire available U.S. Plant Introduction collection of Citrullus Schrad. ex Eckl. \& Zeyh. species was evaluated for resistance to $P$. xanthii race $1 W$. The collection consists of four Citrullus species and one Praecitrullus Pangalo species [C. lanatus var. citroides (L.H. Bailey) Mansf., C. colocynthis (L.) Schrad., C. rehmii De Winter, and $P$. fistulosus (Stocks) Pangalo]. Wild-type accessions tended to be more resistant more often than the cultivated species, C. lanatus var. lanatus. None were immune, eight of the 1573 accessions exhibited high levels of resistance, and another 86 demonstrated intermediate resistance. Stem and leaf disease severity were weakly correlated $\left(r^{2}=0.64, P=0.001\right)$. The majority of accessions having resistance were collected in Zimbabwe. Resistance was found in four species.
\end{abstract}

Powdery mildew affects many cucurbit crops worldwide, limiting yield and increasing the need for fungicide application. Except for a few scattered cases of this disease on watermelon fruit (Ivanoff, 1957; McLean, 1970; Robinson and Provvidenti, 1975), powdery mildew has not been a problem for this crop until recently. Since 1996, a new pathotype of powdery mildew has been damaging watermelon crops in the United States (Davis et al., 2001; Keinath, 2000; McGrath, 2001a). Outbreaks of watermelon powdery mildew pathotypes, races $1 \mathrm{~W}$ and $2 \mathrm{~W}$, on watermelon have been confirmed in South Carolina, Georgia, Florida, Oklahoma, Texas, Maryland, New York, Arizona, and California and were determined using melon (Cucumis melo L.) differentials (Davis et al., 2001; McGrath, 2001a).

Powdery mildew can decrease plant canopy, reduce yields through decreased fruit size and number of fruit per plant, and reduce fruit quality, flavor, and storage life (Keinath and DuBose, 2004; McGrath and Thomas, 1996). The reduced

Received for publication 20 Dec. 2006. Accepted for publication 5 Aug. 2007. This work was partially supported by the Cucurbit Crop Germplasm Committee, the National Germplasm System, USDA, ARS, and a fellowship under the OECD Co-operative Research Programme: Biological Resource Management for Sustainable Agriculture Systems.

We thank Amy Helms and Anthony Dillard for technical assistance and Robert Jarret for supplying seed from the Citrullus species collection. Some melon differentials were kindly supplied by Dr. Claude Thomas.

${ }^{1}$ Corresponding author. E-mail: adavis-usda@lane-ag.org. canopy may also result in sunscald of the remaining fruit, making them unmarketable. Detection of powdery mildew on watermelon can be difficult because the presence of the pathogen is less apparent than on melon. There are at least two symptoms on watermelon: chlorotic spots that occur on leaves accompanied by little or no sporulation and only a small amount of mycelial development, or mycelial and conidial development on either leaf surface with or without the associated chlorotic spots (Davis et al., 2001).

Podosphaera xanthii and Golovinomyces cichoracearum (D.C.) V.P. Heluta (formerly Erysiphe cichoracearum D.C.) are the predominant fungi that incite powdery mildew in cucurbits. These organisms differ in virulence against cucurbit species, and in their sensitivity to fungicides (Bertrand, 1991; Epinat et al., 1993; McGrath, 2001a, 2001b). Only one species, $P$. xanthii, has been reported on watermelon in the United States. Using differential reactions of 10 melon ( $C$. melo) genotypes, seven pathogenically distinct races of $P$. xanthii can be differentiated (McCreight et al., 1987; Pitrat et al., 1998). More recently, McCreight (2006) reported that there may be as many as 28 races of $P$. xanthii on melon based on the reported reactions of 30 melon genotypes with as many as eight variants of race 1 , and six variants of race 2 . The significance of these races defined on melon is not known for watermelon.

Resistance of $P$. xanthii to certain fungicides has been detected, and application of fungicides to undersides of leaves 
Table 1. Ranking of the mean disease severity rating (DSR) from six replicates of Citrullus species and Praecitrullus species PI lines that demonstrated resistance or intermediate resistance to race 1W Podosphaera xanthii.

\begin{tabular}{|c|c|c|c|c|c|c|}
\hline \multirow[b]{2}{*}{ Accession } & \multicolumn{4}{|c|}{ Mean DSR $(1-12 \text { scale })^{\mathrm{z}}$} & \multirow[b]{2}{*}{ Species $^{\mathrm{y}}$} & \multirow[b]{2}{*}{ Seed origin } \\
\hline & Total plant & Leaf & Cotyledon & Stem & & \\
\hline Grif 5601 & 2.0 & 2.0 & 2.0 & 2.0 & $\mathrm{P}$ & India \\
\hline PI 482255 & 2.5 & 2.5 & 2.5 & 2.5 & $\mathrm{~L}$ & Zimbabwe \\
\hline PI 388770 & 2.7 & 3.0 & 2.5 & 2.5 & $\mathrm{Cc}$ & Morocco \\
\hline PI 482362 & 2.7 & 2.5 & 3.0 & 2.5 & $\mathrm{~L}$ & Zimbabwe \\
\hline PI 381750 & 2.8 & 2.5 & 3.5 & 2.5 & $\mathrm{P}$ & India \\
\hline PI 459074 & 2.8 & 3.0 & 3.0 & 2.5 & $\mathrm{~L}$ & Botswana \\
\hline PI 386015 & 3.0 & 3.0 & 3.0 & 3.0 & $\mathrm{Cc}$ & Iran \\
\hline PI 482248 & 3.0 & 3.3 & 3.0 & 2.7 & $\mathrm{~L}$ & Zimbabwe \\
\hline PI 381742 & 3.2 & 2.5 & 4.0 & 3.0 & $\mathrm{P}$ & India \\
\hline PI 532738 & 3.2 & 3.3 & 3.3 & 3.0 & $\mathrm{c}$ & Zaire \\
\hline PI 500331 & 3.3 & 3.4 & 3.2 & 3.4 & $\mathrm{c}$ & Zambia \\
\hline PI 508443 & 3.3 & 4.0 & 3.0 & 3.0 & $\mathrm{~L}$ & South Korea \\
\hline PI 560008 & 3.3 & 3.0 & 4.0 & 3.0 & $\mathrm{~L}$ & Nigeria \\
\hline PI 525082 & 3.4 & 4.0 & 3.5 & 2.8 & $\mathrm{Cc}$ & Egypt \\
\hline PI 482264 & 3.4 & 3.3 & 3.7 & 3.3 & $\mathrm{~L}$ & Zimbabwe \\
\hline PI 482258 & 3.5 & 3.5 & 3.5 & 3.5 & $\mathrm{~L}$ & Zimbabwe \\
\hline PI 217938 & 3.6 & 3.7 & 3.3 & 3.7 & $\mathrm{P}$ & Pakistan \\
\hline PI 250145 & 3.6 & 4.0 & 3.3 & 3.3 & $\mathrm{P}$ & Pakistan \\
\hline PI 482333 & 3.6 & 3.3 & 3.7 & 3.7 & c & Zimbabwe \\
\hline PI 526233 & 3.6 & 4.0 & 3.3 & 3.3 & $\mathrm{~L}$ & Zimbabwe \\
\hline PI 482313 & 3.6 & 3.8 & 3.5 & 3.5 & $\mathrm{~L}$ & Zimbabwe \\
\hline PI 482328 & 3.6 & 3.5 & 3.8 & 3.5 & $\mathrm{~L}$ & Zimbabwe \\
\hline PI 500323 & 3.6 & 4.0 & 3.4 & 3.4 & $\mathrm{~L}$ & Zambia \\
\hline PI 505585 & 3.6 & 3.8 & 3.6 & 3.4 & $\mathrm{~L}$ & Zambia \\
\hline PI 169241 & 3.7 & 3.0 & 4.0 & 4.0 & $\mathrm{~L}$ & Turkey \\
\hline PI 179239 & 3.7 & 4.0 & 3.5 & 3.5 & $\mathrm{~L}$ & Turkey \\
\hline PI 179881 & 3.7 & 3.0 & 4.5 & 3.5 & $\mathrm{c}$ & India \\
\hline PI 179885 & 3.7 & 4.0 & 4.0 & 3.0 & $\mathrm{~L}$ & India \\
\hline PI 184800 & 3.7 & 4.0 & 3.5 & 3.5 & $\mathrm{~L}$ & Nigeria \\
\hline PI 271749 & 3.7 & 4.0 & 3.7 & 3.3 & $\mathrm{~L}$ & Afghanistan \\
\hline PI 296334 & 3.7 & 3.3 & 4.5 & 3.3 & $\mathrm{c}$ & South Africa \\
\hline PI 381731 & 3.7 & 3.5 & 4.0 & 3.5 & $\mathrm{~L}$ & India \\
\hline PI 386025 & 3.7 & 4.5 & 3.5 & 3.0 & $\mathrm{Cc}$ & Iran \\
\hline PI 482251 & 3.7 & 3.3 & 3.8 & 4.0 & $\mathrm{~L}$ & Zimbabwe \\
\hline PI 482278 & 3.7 & 3.8 & 4.0 & 3.3 & $\mathrm{~L}$ & Zimbabwe \\
\hline PI 482295 & 3.7 & 3.5 & 4.0 & 3.5 & $\mathrm{~L}$ & Zimbabwe \\
\hline PI 482302 & 3.7 & 3.3 & 3.8 & 4.0 & $\mathrm{c}$ & Zimbabwe \\
\hline PI 482355 & 3.7 & 3.3 & 4.0 & 3.8 & $\mathrm{c}$ & Zimbabwe \\
\hline PI 500332 & 3.7 & 3.3 & 4.3 & 3.5 & $\mathrm{c}$ & Zambia \\
\hline PI 512343 & 3.7 & 3.0 & 5.0 & 3.0 & $\mathrm{~L}$ & Spain \\
\hline PI 525088 & 3.7 & 3.3 & 4.0 & 3.7 & $\mathrm{~L}$ & Egypt \\
\hline PI 482312 & 3.7 & 3.8 & 3.5 & 3.8 & $\mathrm{c}$ & Zimbabwe \\
\hline PI 482259 & 3.7 & 4.0 & 3.8 & 3.4 & $\mathrm{c}$ & Zimbabwe \\
\hline PI 482308 & 3.7 & 4.0 & 3.6 & 3.6 & $\mathrm{c}$ & Zimbabwe \\
\hline PI 482380 & 3.7 & 3.6 & 3.8 & 3.8 & $\mathrm{~L}$ & Zimbabwe \\
\hline PI 500334 & 3.7 & 3.8 & 3.6 & 3.8 & $\mathrm{c}$ & Zambia \\
\hline PI 270545 & 3.8 & 3.5 & 4.0 & 3.8 & $\mathrm{~L}$ & Sudan \\
\hline PI 482268 & 3.8 & 4.3 & 3.5 & 3.5 & $\mathrm{~L}$ & Zimbabwe \\
\hline Grif 5602 & 3.8 & 3.7 & 4.3 & 3.3 & $\mathrm{P}$ & India \\
\hline PI 189318 & 3.8 & 3.7 & 3.7 & 4.0 & $\mathrm{~L}$ & Nigeria \\
\hline PI 500302 & 3.8 & 3.7 & 4.0 & 3.7 & $\mathrm{c}$ & Zambia \\
\hline PI 500308 & 3.8 & 3.8 & 4.0 & 3.6 & $\mathrm{c}$ & Zambia \\
\hline PI 500342 & 3.8 & 3.8 & 3.6 & 4.0 & $\mathrm{~L}$ & Zambia \\
\hline PI 179875 & 3.8 & 4.0 & 4.3 & 3.3 & $\mathrm{P}$ & India \\
\hline PI 180275 & 3.8 & 3.5 & 4.5 & 3.5 & $\mathrm{P}$ & India \\
\hline
\end{tabular}

is difficult and often requires the use of systemic materials to achieve adequate control of the disease (McGrath and Thomas, 1996). Recent work by Keinath and DuBose (2004) demonstrated effective control of powdery mildew race $2 \mathrm{~W}$ on watermelon by alternating preventative applications of two fungicides: mancozeb and azoxystrobin.

Use of resistant watermelon cultivars in addition to fungicide applications should slow development of $P$. xanthii resistance to fungicides. We initially screened 100 watermelon plant introduction (PI) accessions for resistance to watermelon race $1 \mathrm{~W}$ of $P$. xanthii (Davis et al., 2001). This led to the release of watermelon breeding line (PI 525088-PMR), which has intermediate resistance to race $1 \mathrm{~W} P$. xanthii (Davis et al., 2006a). The inheritance of resistance in that line to race $1 \mathrm{~W}$ is multigenic (Davis et al., 2002) and appears to be independent from resistance to $P$. xanthii race $2 \mathrm{~W}$ (Davis et al., 2002, 2006b; Thomas et al., 2005). In the current study, we screened the entire available U.S. Department of Agriculture, Agricultural Research Service (USDAARS), National Genetic Resources Program (NPGS) watermelon accessions for resistance to race $1 \mathrm{~W}$ to identify additional resistance genes for control of this race.

\section{Materials and Methods}

Plant material. A total of 1573 Citrullus species and tinda (P. fistulosus) accessions from NPGS at the Southern Regional Plant Introduction Station, USDA-ARS, Griffin, $\mathrm{GA}$, were evaluated. The accessions represent 75 countries of origin and five species, belonging to $C$. lanatus var. lanatus, C. lanatus var. citroides, C. colocynthis, C. rehmii, and P. fistulosus.

Ten $C$. melo differentials were included in all experiments to determine the race of $P$. xanthii present: 'Delicious 51', 'Edisto 47', Iran H, MR-1, 'Nantais Oblong', PI 124112, PI 414723, 'PMR 45', 'PMR 5', 'PMR 6', WMR 29, and 'Top Mark'. Differentials were supplied by C. Thomas and M. Pitrat and were included in all studies to verify the 
Table 1. Continued.

\begin{tabular}{|c|c|c|c|c|c|c|}
\hline \multirow[b]{2}{*}{ Accession } & \multicolumn{4}{|c|}{ Mean DSR $(1-12 \text { scale })^{\mathrm{z}}$} & \multirow[b]{2}{*}{ Species $^{\mathrm{y}}$} & \multirow[b]{2}{*}{ Seed origin } \\
\hline & Total plant & Leaf & Cotyledon & Stem & & \\
\hline PI 277971 & 3.8 & 3.8 & 4.0 & 3.8 & $\mathrm{~L}$ & Turkey \\
\hline PI 277994 & 3.8 & 3.5 & 4.5 & 3.5 & $\mathrm{~L}$ & Turkey \\
\hline PI 279461 & 3.8 & 4.5 & 3.5 & 3.5 & $\mathrm{~L}$ & Japan \\
\hline PI 379226 & 3.8 & 3.5 & 4.0 & 4.0 & $\mathrm{~L}$ & Yugoslavia \\
\hline PI 381725 & 3.8 & 4.0 & 3.8 & 3.8 & $\mathrm{~L}$ & India \\
\hline PI 482318 & 3.8 & 3.8 & 4.0 & 3.8 & $\mathrm{~L}$ & Zimbabwe \\
\hline PI 482341 & 3.8 & 4.3 & 3.8 & 3.5 & $\mathrm{~L}$ & Zimbabwe \\
\hline PI 482365 & 3.8 & 3.8 & 4.3 & 3.5 & $\mathrm{~L}$ & Zimbabwe \\
\hline PI 500337 & 3.8 & 3.0 & 4.0 & 4.5 & $\mathrm{~L}$ & Zambia \\
\hline PI 500338 & 3.8 & 3.8 & 4.0 & 3.8 & $\mathrm{~L}$ & Zambia \\
\hline PI 500350 & 3.8 & 4.0 & 4.0 & 3.5 & $\mathrm{~L}$ & Zambia \\
\hline PI 525083 & 3.8 & 4.0 & 3.8 & 3.8 & $\mathrm{c}$ & Egypt \\
\hline PI 526239 & 3.8 & 4.5 & 3.3 & 3.8 & $\mathrm{~L}$ & Zimbabwe \\
\hline PI 559994 & 3.8 & 4.0 & 3.5 & 4.0 & $\mathrm{~L}$ & Nigeria \\
\hline PI 632755 & 3.8 & 3.5 & 4.0 & 4.0 & $\mathrm{R}$ & Namibia \\
\hline PI 482252 & 3.9 & 4.0 & 3.6 & 4.0 & $\mathrm{c}$ & Zimbabwe \\
\hline PI 482319 & 3.9 & 3.6 & 4.0 & 4.0 & $\mathrm{c}$ & Zimbabwe \\
\hline PI 181936 & 3.9 & 3.7 & 4.3 & 3.7 & $\mathrm{~L}$ & Syria \\
\hline PI 183398 & 3.9 & 3.7 & 3.7 & 4.3 & $\mathrm{~L}$ & India \\
\hline PI 233556 & 3.9 & 4.3 & 4.0 & 3.3 & $\mathrm{~L}$ & Japan \\
\hline PI 278006 & 3.9 & 3.7 & 4.0 & 4.0 & $\mathrm{~L}$ & Turkey \\
\hline PI 381737 & 3.9 & 3.7 & 4.0 & 4.0 & $\mathrm{~L}$ & India \\
\hline PI 381748 & 3.9 & 3.7 & 4.3 & 3.7 & $\mathrm{P}$ & India \\
\hline PI 500301 & 3.9 & 3.7 & 4.3 & 3.7 & $\mathrm{~L}$ & Zambia \\
\hline PI 500312 & 3.9 & 4.2 & 3.5 & 4.0 & $\mathrm{~L}$ & Zambia \\
\hline PI 247398 & 3.9 & 4.3 & 3.8 & 3.8 & $\mathrm{~L}$ & Greece \\
\hline PI 381753 & 3.9 & 4.0 & 4.0 & 3.8 & $\mathrm{P}$ & India \\
\hline PI 482269 & 3.9 & 4.3 & 3.8 & 3.8 & $\mathrm{~L}$ & Zimbabwe \\
\hline PI 482346 & 3.9 & 4.0 & 3.8 & 4.0 & $\mathrm{~L}$ & Zimbabwe \\
\hline PI 482366 & 3.9 & 4.0 & 3.8 & 4.0 & $\mathrm{~L}$ & Zimbabwe \\
\hline PI 482377 & 3.9 & 4.3 & 3.8 & 3.8 & $\mathrm{~L}$ & Zimbabwe \\
\hline PI 508441 & 3.9 & 4.5 & 3.5 & 3.8 & $\mathrm{~L}$ & South Korea \\
\hline PI 559997 & 3.9 & 3.8 & 4.0 & 4.0 & $\mathrm{~L}$ & Nigeria \\
\hline PI 482288 & 3.9 & 4.0 & 4.0 & 3.8 & $\mathrm{~L}$ & Zimbabwe \\
\hline PI 482307 & 3.9 & 4.0 & 4.0 & 3.8 & $\mathrm{c}$ & Zimbabwe \\
\hline PI 482373 & 3.9 & 4.0 & 4.0 & 3.8 & $\mathrm{~L}$ & Zimbabwe \\
\hline PI 482378 & 3.9 & 3.8 & 3.8 & 4.2 & $\mathrm{~L}$ & Zimbabwe \\
\hline PI 505595 & 3.9 & 4.0 & 4.0 & 3.8 & $\mathrm{~L}$ & Zambia \\
\hline
\end{tabular}

${ }^{\mathrm{z}}$ Accessions were classified into resistant, intermediate, or susceptible classifications according to the DSR of six replicates for total plant (leaf, stem, and cotyledon). Lines were considered resistant if their total plant mean DSR was $\leq 3.0$, intermediate if $3.1-4$, and susceptible if $\geq 4.1$.

${ }^{\mathrm{y}} \mathrm{L}=$ Citrullus lanatus var. lanatus; $\mathrm{c}=$ C. lanatus var. citroides $; \mathrm{Cc}=$ Citrullus colocynthis; $\mathrm{P}=$ Praecitrullus fistulosus; $\mathrm{R}=$ Citrullus rehmii .

powdery mildew race present. Race $1 \mathrm{~W}$ was the only race detected in all experiments.

GREENHOUSE EXPERIMENTS. One seed each of the available Citrullus species and P. fistulosus PI accessions was randomly planted in Speedling flats (Sun City, FL) containing Redi-earth growth media (Scotts-Sierra Horticultural Products Co., Marysville, $\mathrm{OH}$ ) in a greenhouse experiment with six replications. Replications were not performed concurrently. Seedlings were inoculated with the Lane, $\mathrm{OK}$, race $1 \mathrm{~W} P$. xanthii isolate maintained on greenhouse-grown watermelon plants. Plants were inoculated two times a week for 3 weeks by brushing an infected leaf onto each seedling, starting at the two-leaf stage of growth. The plants were maintained under normal greenhouse conditions, and night/day temperatures were maintained by an automated system between 25 and $33{ }^{\circ} \mathrm{C}$. Ratings were taken when $50 \%$ of the leaf surface area of susceptible differentials was visibly infected. Ratings were performed no later than 2 months after planting. Three ratings were made of each plant (stem, upper side of the leaves, and cotyledons) using the nonlinear 12-point method (Horsfall and Barratt, 1945). Accessions were classified into resistant, intermediate, or susceptible classifications according to the mean disease severity rating (DSR) of six replicates for total plant (leaf, stem, and cotyledon): $\leq 6 \%$, resistant; $>6 \%$ and $\leq 12 \%$, intermediate; and $>12 \%$, susceptible. Out of 1573 PI lines tested, 13 did not germinate or experienced early death of seedlings.

A retest was performed on $35 \mathrm{PI}$ accessions chosen for their geographical diversity from the $50 \mathrm{PI}$ lines with the lowest average total plant ratings. Thirteen countries and three species or subspecies (C. lanatus var. lanatus, C. lanatus var. citroides, and C. colocynthis) were represented in the retest. Five replications of one plant of each selected PI accession were planted in a randomized complete block design, inoculated, and rated as above.

Statistical analysis. Data were transformed to real numbers and the data were analyzed with PROC GLM and PROC CORR using SAS (version 7; SAS Institute, Cary, NC). The data are summarized as averages of the replications for each study in Tables 1 and 2.

\section{Results and Discussion}

Evaluation of watermelon PI ACCESSIONS FOR RACE $1 \mathrm{~W} P$. XANTHII RESISTANCE. The $P$. xanthii strain present was race 1 as defined by the susceptibility of the following melon differentials: 'Delicious 51', Iran H, 'Nantais Oblong', and 'Top Mark' and resistance of all the other melon race differentials. Susceptibility of watermelon indicated that it was race $1 \mathrm{~W}$ pathotype.

In each of the six replications, there was a range of symptoms from no detectable mycelia to $97 \%$ coverage on the entire plant. The majority of the PI accessions (92\%) had mean detectable mycelia covering $12 \%$ to $50 \%$ of the plant surface (data not shown). Less than $1 \%$ of the PI accessions tested showed high or intermediate resistance. The 93 PI accessions with an average DSR below four $(<12 \%$ mycelia coverage) for all plant parts tested (leaf, stem, and cotyledon) are listed in Table 1. In our judgment, all 93 of these accessions 
Table 2. Ranking of the mean disease severity rating (DSR) for the retested Citrullus species PI lines for race 1W Podosphaera xanthii resistance.

\begin{tabular}{|c|c|c|c|c|c|c|c|}
\hline \multirow[b]{2}{*}{ Accession no. } & \multicolumn{3}{|c|}{ Mean DSR $(1-12 \text { scale })^{z}$} & \multirow[b]{2}{*}{ Accession no. } & \multicolumn{3}{|c|}{ Mean DSR $(1-12 \text { scale })^{z}$} \\
\hline & Total plant & Leaf & Stem & & Total plant & Leaf & Stem \\
\hline 388770 & 1.3 & 1.3 & 1.3 & 526233 & 3.5 & 3.7 & 3.3 \\
\hline 505585 & 1.5 & 1.5 & 1.5 & 482255 & 3.5 & 4.0 & 3.0 \\
\hline 270545 & 2.0 & 2.0 & 2.0 & 512343 & 3.5 & 4.0 & 3.0 \\
\hline 482308 & 2.0 & 2.0 & 2.0 & 482268 & 3.8 & 4.3 & 3.3 \\
\hline 482312 & 2.0 & 2.0 & 2.0 & 482264 & 3.8 & 4.3 & 3.3 \\
\hline 482333 & 2.0 & 2.0 & 2.0 & 179881 & 4.0 & 4.0 & 4.0 \\
\hline 525082 & 2.3 & 2.0 & 2.5 & 184800 & 4.0 & 4.0 & 4.0 \\
\hline 500323 & 2.5 & 2.5 & 2.5 & 381731 & 4.0 & 4.0 & 4.0 \\
\hline 482278 & 2.8 & 3.0 & 2.5 & 560008 & 4.0 & 4.0 & 4.0 \\
\hline 482328 & 2.8 & 3.0 & 2.7 & 459074 & 4.0 & 4.5 & 3.5 \\
\hline 500331 & 3.0 & 3.0 & 3.0 & 500332 & 4.4 & 4.5 & 4.2 \\
\hline 482362 & 3.3 & 3.8 & 2.8 & & & & \\
\hline
\end{tabular}

${ }^{\mathrm{z}}$ Accessions were classified into resistant, intermediate, or susceptible classifications according to the DSR for total plant (leaf, stem, and cotyledon). Lines were considered resistant if their total plant mean DSR was $\leq 3.0$, intermediate if $3.1-4$, and susceptible if $\geq 4.1$.

Table 3. Number and percentage of each species analyzed demonstrating resistance and intermediate resistance to race $1 \mathrm{~W}$ Podosphaera xanthii.

\begin{tabular}{lccc}
\hline & & Proportion of PI \\
collection these \\
Species & Accessions (no.) & Accessions (\%) & 1.9 \\
species represent (\%)
\end{tabular}

${ }^{\mathrm{z}}$ Number of accessions analyzed from each species demonstrating low $(<4)$ total plant disease severity ratings [DSR (1-12 scale)]. Accessions were classified into resistant, intermediate, or susceptible classifications according to the DSR for total plant (leaf, stem, and cotyledon). Lines were considered resistant if their total plant mean DSR was $\leq 3.0$, intermediate if $3.1-4$, and susceptible if $\geq 4$. 1 .

yPercentage of accessions analyzed from each species demonstrating low $(<4)$ total plant DSR. only stem ratings (Grif 5601 and PIs 482255, 482362, 381750, 388770, 459074, 482248, 525082, 381742, 386015, 560008, 512343, 532738, 266028, 508443, 179885, 512375, 512367, 386025, 219907, 248178). All PI accessions that demonstrated leaf resistance were also rated resistant when using the stem rating. All but one PI accession demonstrating stem resistance showed high or intermediate resistance on the leaf.

In the retest (Table 2), 15 PI accessions were rated as resistant (388770, 505585, 386015, 270545, 482308, 482312, 482313, 482333, 525082, 500323, 482278, 482328, 500331, 508443, 169241). This increase in number of resistant accessions may be due to cotyledon ratings not being considered. Four PI

had commercially useful resistance to the disease. All accessions in Table 1 were determined to be resistant ( $\leq 6 \%$ mycelia) or have intermediate resistance (between $>6 \%$ and $\leq 12 \%$ mycelia).

When total plant DSRs were used to rank PI accessions for resistance, only eight accessions (Grif 5601 and PIs 482255, 388770, 482362, 381750, 459074, 386015, and 482248) were considered resistant with a DSR value $\leq 3.0$. Only eight PI accessions were resistant when only the cotyledon DSRs were analyzed (Grif 5601 and PIs 482255, 388770, 482362, 459074, 386015,482248 , and 508443), but this number increased to 13 PI accessions when only the mean of the leaf rating was analyzed (Grif 5601 and PIs 482255, 482362, 381750, 381742, 388770, 459074, 386015, 560008, 169241, 179881, 512343, 500337) and increased again to 21 resistant accessions when we analyzed accessions rated resistant in the initial screen had only intermediate resistance in the retest $(482248,482362,482255$, 459074). Only PI 388770 and 386015 demonstrated total plant resistance in both experiments. No PI lines were completely free of mycelia on all plant parts when data from all experiments were combined.

PIs 459074 and 525088, reported resistant in field trials (Davis et al., 2002), were among the 40 accessions most resistant to race $1 \mathrm{~W}$ (Table 1). PI 482291 and PI 186490, previously resistant in field trials (Davis et al., 2002), were susceptible in these greenhouse tests. The newly released race $1 \mathrm{~W}$ powdery mildew resistant inbred PI 525088-PMR (Davis et al., 2006a) was not included in these tests, but PI 525088, which came from the same original seed source, was included and was ranked among the 40 most resistant accessions. 
Correlation of DSR for leAF, STEM, AND COTYLEDON. A correlation was performed between DSR of the three tissues tested. The transformed means of the original six replicates for each of the 1573 PI accessions were used. There were significant, yet weak, correlations between leaf disease ratings and stem ratings $(r=0.64 ; P=0.001)$, leaf and cotyledon ratings $(r=0.20 ; P=0.001)$, and stem and cotyledon ratings $(r=0.24 ; P$ $=0.001)$. Similarly, the correlation between stem and leaf for the retested PI accessions was significant but weak $(r=0.68 ; P=$ $0.001)$. Cotyledon ratings were not taken on the retest. The data from these two experiments indicate that disease resistance for cotyledons is controlled by different genes than for leaf and stem resistance. This was also true in melon PI 313970 resistance to races 1 and 2 (McCreight, 2003). The DSR for leaf, stem, and cotyledon showed that cotyledon and leaf tissue have, on average, higher DSRs then stem. Because stems had lower DSRs overall than leaves, the limited correlation may be due to amount of mycelia present rather than presence or absence of resistance genes for these two tissues.

Because leaves make up the most significant surface area of watermelon plants, breeding for leaf resistance is likely more important than stem or cotyledon resistance. However, in severe powdery mildew cases, cotyledons can be heavily infected, stunting or even killing the seedlings. Whole-plant resistance is, therefore, desirable.

Heterogeneity of Resistance within PI lines. Many of the PI accessions, which are usually open pollinated, showed phenotypic variability (heterogeneity) for disease resistance, which reduced their total plant ranking for these accessions; individuals in one accession ranged from $6 \%$ to $94 \%$ total plant coverage with mycelia. Average standard deviation of ratings within PI accessions was $20 \%$ (range, $0 \%$ to $45 \%$ ). This suggests that there are accessions heterogeneous for resistance. While DSRs varied slightly between individual plants within each of the susceptible control differentials across replications, they were still clearly susceptible plants.

Resistance to $P$. XaNTHII RACE 1 W In CitrulluS SPECIES AND P. Fistulosus. There was a high percentage of $P$. fistulosus (11\%) and $C$. colocynthis (4\%) in the 93 accessions most resistant to race $1 \mathrm{~W}$ (Table 3 ); these two species comprise $<2 \%$ of the Citrullus species PI collection. P. fistulosus is distantly related to the genus Citrullus (Levi et al., 2005); it has a chromosome number of $n=x=12$, while Citrullus has $n=x=$ 11 and no interspecific crosses have been reported (Robinson and Decker-Walters, 1997).

When analyzed by geographical origin, $36 \%$ and $15 \%$ of the 93 most resistant accessions were from Zimbabwe and Zambia, respectively, although they constitute only $9 \%$ and $4 \%$ of the U.S. Citrullus species PI collection (data not shown). These data indicate the origin of most of the resistant accessions in this study was from this region of Africa. Accessions from 13 countries were selected in the retests and are being inbred for uniform reaction to powdery mildew race $1 \mathrm{~W}$. We will perform inheritance studies and allelism tests on these lines to identify multiple resistance genes, to incorporate multiple resistance sources into a single cultivar to offer greater resistance stability.

Powdery mildew on cucurbits is a rapidly evolving disease with serious impact on cucurbit production worldwide. Therefore, resistance screening to emerging races and pathotypes and development of differential lines that can be used to detect these different forms of the fungus are of great importance.
Cucurbit powdery mildew in the United States was not known to infect watermelon before 1996. A new pathotype of cucurbit powdery mildew defined by the ability to infect watermelon has since spread throughout the United States. All strains tested to date that colonize watermelon are able to colonize some of the melon differentials, but not all strains colonizing melon are able to cause disease symptoms on watermelon (Davis et al., 2006a, 2006b).

The melon differentials used in this study defined which melon race of the watermelon pathotype was present; there are no formally released Citrullus species powdery mildew differentials at this time. Watermelon lines are currently being developed that have homogeneous reaction to inoculation with these two watermelon pathotypes of $P$. xanthii. Once produced, it is likely that the $P$. xanthii races affecting watermelon will differ from that which infects melon. Because of this, it is suggested that the nomenclature used in this article be adapted to differentiate between the pathotypes. Races could be differentiated by indicating race $1 \mathrm{M}$ (or $2 \mathrm{M}$ or $3 \mathrm{M}$ ) according to the reaction of a melon differential set and race $1 \mathrm{~W}$ or $2 \mathrm{~W}$ according to the reaction of watermelon differentials. For instance, a strain could belong to race $2 \mathrm{M}$ (on melon) and $1 \mathrm{~W}$ (on watermelon).

\section{Literature Cited}

Bertrand, F. 1991. Les oïdiums des cucurbitacées: maintien en culture pure, étude de leur variabilité et de la sensibilité chez le melon. Ph.D. Diss. Université of Paris XI, Orsay, France.

Davis, A.R., A. Levi, T. Wehner, and M. Pitrat. 2006a. PI 525088PMR, a melon race 1 powdery mildew resistant watermelon line. HortScience 41:1527-1528.

Davis, A.R., A. Tetteh, T. Wehner, A. Levi, and M. Pitrat. 2006 b. Watermelon resistance to powdery mildew race 1 and race 2, p. $412-$ 420. In: G.J. Holmes (ed.). Proc. Cucurbitaceae 2006. Universal Press, Raleigh, NC.

Davis, A.R., B.D. Bruton, S.D. Pair, and C.E. Thomas. 2001. Powdery mildew: an emerging disease of watermelon in the United States. Cucurbit Genet. Coop. Rpt. 24:42-48.

Davis, A.R., C.E. Thomas, A. Levi, B.D. Bruton, and S.D. Pair. 2002. Watermelon resistance to powdery mildew race 1, p. 192-198. In: D.N. Maynard (ed.). Cucurbitaceae '02. ASHS Press, Alexandria, VA.

Epinat, C., M. Pitrat, and F. Bertrand. 1993. Genetic analysis of resistance of five melon lines to powdery mildews. Euphytica 65:135-144.

Horsfall, J.G. and R.W. Barratt. 1945. An improved grading system for measuring plant disease. Phytopathology 35:655 (abstr.).

Ivanoff, S.S. 1957. Powdery mildew pimples of watermelon fruits. Phytopathology 47:599-602.

Keinath, A.P. 2000. Effect of protectant fungicide application schedules on gummy stem blight epidemics and marketable yield of watermelon. Plant Dis. 84:254-260.

Keinath, A.P. and B. DuBose. 2004. Evaluation of fungicides for prevention and management of powdery mildew on watermelon. Crop Prot. 23:35-42.

Levi, A., C.E. Thomas, A.M. Simmons, and J.A. Thies. 2005. Analysis based on RAPD and ISSR markers reveals closer similarities among Citrullus and Cucumis species than with Praecitrullus fistulosus (Stocks) Pangalo. Genet. Resources Crop Evol. 52: 465-472.

McCreight, J.D. 2003. Genes for resistance to powdery mildew races 1 and 2 US in melon PI 313970. HortScience 38:591-594.

McCreight, J.D. 2006. Melon-powdery mildew interactions reveal variation in melon cultigens and Podosphaera xanthii races 1 and 2. J. Amer. Soc. Hort. Sci. 131:59-65. 
McCreight, J.D., M. Pitrat, C.E. Thomas, A.N. Kishaba, and G.W. Bohn. 1987. Powdery mildew resistance genes in muskmelon. J. Amer. Soc. Hort. Sci. 112:156-160.

McGrath, M.T. 2001a. Distribution of cucurbit powdery mildew races 1 and 2 on watermelon and muskmelon. Phytopathology 91:197 (abstr.).

McGrath, M. 2001b. Fungicide resistance in cucurbit powdery mildew: experiences and challenges. Plant Dis. 85:236245.

McGrath, M.T. and C.E. Thomas. 1996. Powdery mildew, p. 28-30. In: T.A. Zitter, D.L. Hopkins, and C.E. Thomas (eds.). Compendium of cucurbit diseases. The American Phytopathological Society, St. Paul, MN.
McLean, D.M. 1970. Powdery mildew on watermelon fruits. Plant Dis. Rpt. 54:372-373.

Pitrat, M., C. Dogimont, and M. Bardin. 1998. Resistance to fungal diseases of foliage in melon, p. 167-173. In: J.D. McCreight (ed.). Cucurbitaceae '98. ASHS Press, Alexandria, VA.

Robinson, R.W. and R. Provvidenti. 1975. Susceptibility to powdery mildew in Citrullus lanatus (Thunb.). Matsum. \& Nakai. J. Amer. Soc. Hort. Sci. 100:328-330.

Robinson, R.W. and D.S. Decker-Walters. 1997. Cucurbits, p. 40. CAB International, New York.

Thomas, C.E., A. Levi, and E. Caniglia. 2005. Evaluation of U.S. plant introductions of watermelon for resistance to powdery mildew. HortScience 40:154-156. 